\title{
Cyclometallated Ir(III), Rh(III) and Ru(II) complexes as catalysts for the cyclotrimerisation of 1,6-diynes with monoynes
}

\author{
Ronald Grigg, ${ }^{\mathrm{a} * 1}$ Colin Kilner, ${ }^{\mathrm{a}}$ Meena Senthilnanthanan, ${ }^{\mathrm{a}}$ Ché R. Seabourne, \\ Visuvanathar Sridharan, ${ }^{a}$ and Barry A. Murrer $^{\text {b }}$ \\ ${ }^{a}$ Molecular Innovation, Diversity and Automated Synthesis (MIDAS) Centre, School of \\ Chemistry, The University of Leeds, Leeds LS2 9JT \\ ${ }^{b}$ Johnson Matthey, Blounts Court, Sonning Common, Reading RG4 9NH \\ E-mail: r.grigg@leeds.ac.uk
}

\begin{abstract}
A new series of $\mathrm{Rh}, \mathrm{Ir}$ and $\mathrm{Ru}$ precatalysts for the [2+2+2] cyclotrimerisation of 1,6-diynes with monoynes is reported. The precatalysts are reduced in situ to the active catalysts by reduction with alcohols. The precatalysts activity is in the order $\mathrm{Ru}>\mathrm{Rh}>\mathrm{Ir}$ which reflects the ease of this reduction. The $\mathrm{Rh}$ and $\mathrm{Ir}$ precatalysts require temperature in excess of $140{ }^{\circ} \mathrm{C}$ allowing their preparation in 2-methoxymethanol at $125^{\circ} \mathrm{C}$. The mechanism of this process is discussed.
\end{abstract}

Keywords: Cyclometallated complexes, cyclotrimerisation, diynes, precatalysts

\section{Introduction}

The exploitation of cyclometallated complexes in catalysis has recently evolved as a broad new strategy. A variety of palladacycles incorporating cyclometallated phosphines, ${ }^{1}$ phosphites, ${ }^{2}$ carbenes, ${ }^{3}$ imines, ${ }^{4}$ heterocycles, ${ }^{5}$ thioethers, ${ }^{6}$ and oximes ${ }^{7}$ have been reported to catalyse carbon-carbon (Heck, Suzuki) and carbon-nitrogen bond forming processes with high turnover numbers. ${ }^{8,9}$ Additionally, chiral palladacycles have been shown to catalyse carbon-carbon bond forming processes such as the aldol reaction, ${ }^{10}$ Michael addition ${ }^{11}$ and cyclopropanation reactions ${ }^{12}$ with high enantiomeric excesses. Studies on the synthesis and catalytic behaviour of orthometallated complexes of $\mathrm{Rh}(\mathrm{II})^{13}, \mathrm{Rh}(\mathrm{III})^{14}, \operatorname{Ir}(\mathrm{I})^{15}$, and $\mathrm{Ru}(\mathrm{II})^{16}$ have revealed active catalysts of high efficiency. For example, Nishiyama et al. reported that the chiral orthometallated rhodium (III) complex 1 effects the catalytic enantioselective allylation of aldehydes. ${ }^{17}$ Other useful applications of the cyclometallated transition metal complexes include electroluminescent/photoluminescent devices ${ }^{18}$ and antibacterial agents. ${ }^{19}$

\footnotetext{
${ }^{1}$ Ron Grigg was Chairman of the RSC Heterocyclic Group during the period 1983-1985.
} 


\section{Results and Discussion}

In this paper we report the synthesis of cyclometallated $R h(I I I), \operatorname{Ir}(\mathrm{III})$ and $\mathrm{Ru}(\mathrm{II})$ complexes and their application as precatalysts for cyclotrimerisation of 1,6-diynes with monoynes. These were postulated as potential precatalysts that upon in situ reduction would liberate coordinatively unsaturated non-phosphine ligated $\mathrm{M}(\mathrm{I}) / \mathrm{M}(0)$ catalysts. Initally we explored the synthesis of ortho-metallated complexes of $\operatorname{Rh}(\mathrm{III})$ and $\operatorname{Ir}(\mathrm{III})$ with $N$-phenylpyrazole as the ligand (for the first generation catalysts) employing the protocol used by Nonoyama for their synthesis. ${ }^{20}$ Thus the corresponding transition metal chloride and $\mathrm{N}$-phenylpyrazole in 2-methoxyethanol under reflux afforded the dimeric complexes $\mathbf{2 a , b}$ in 55-65\% yield. Attempts to prepare cycloruthenated complexes by the same method failed, yielding a black powdery substance believed to Ru black. Hence, the ortho-metallated ruthenium(II) complex 4 was prepared in 61\% yield by transmetallation of the corresponding mercury(II) complex 3 with $\left[\mathrm{Ru}(\mathrm{p} \text {-cymene }) \mathrm{Cl}_{2}\right]_{2}$ in acetonitrile at room temperature $(\mathrm{Scheme} 1)^{21}$ or stirring $\left[\mathrm{Ru}(p \text {-cymene }) \mathrm{Cl}_{2}\right]_{2}$ and $\mathrm{N}$-phenyl pyrazole in the presence of sodium acetate in DCM at room temperature which afford 4 in $73 \%$ yield Confirmation of the structure of $\mathbf{4}$ was provided by X-ray crystallography (Figure 1).

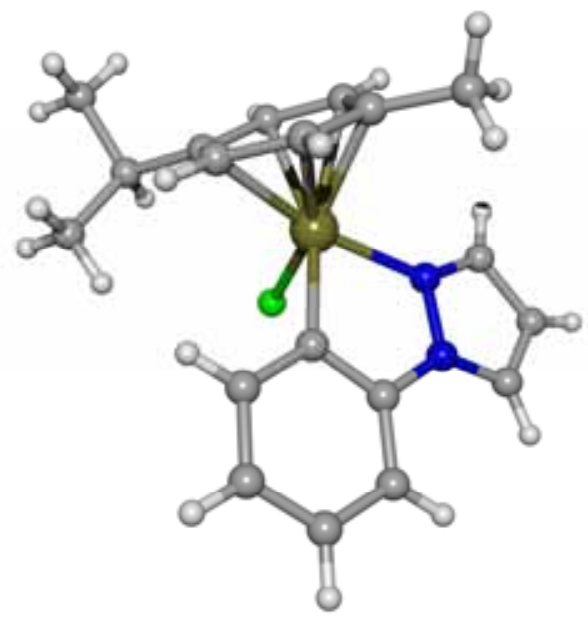

\section{Figure 1}<smiles></smiles>

2 a. $M=R h$ b. $M=I r$
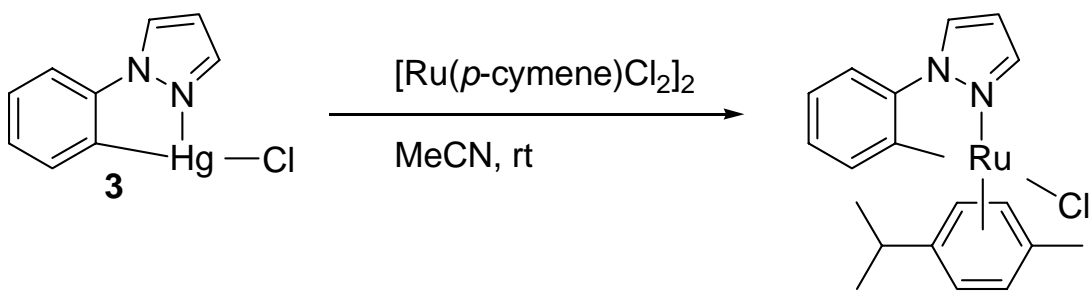

4

Sheme 1 
Next we varied the electronic/steric properties of the ligands employing 2phenylbenzothiazole, $N$ - (m-methoxyphenyl)pyrazole, and 3,5-dimethyl-2-phenylpyrazole as ligands in the preparation of cyclometallated complexes $\mathbf{5}$ and $\mathbf{6}$ as second generation precatalysts. Dimeric cyclometallated complexes 5a,b were obtained in 77-86\% yield. Complex 6 was obtained in $45 \%$ yield and its X-ray crystal structure established that it was a monomer (Figure 2). Steric hindrance of the methyl groups on the pyrazole ring of the ligand prevent formation of the dimeric $\mathrm{Rh}(\mathrm{III})$ complex.

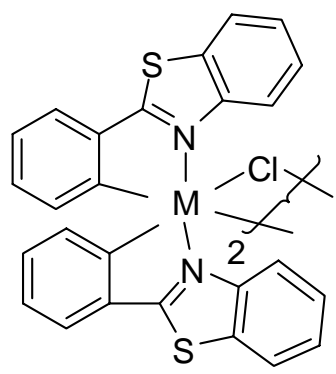

5 a. $M=R h$

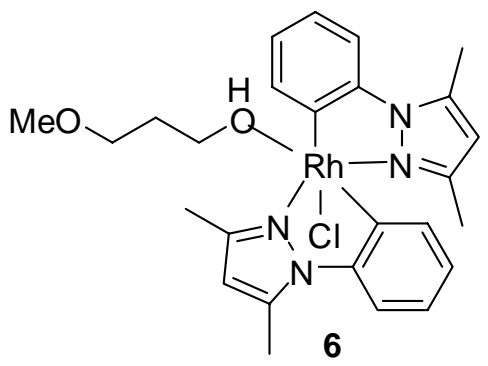

b. $M=I r$

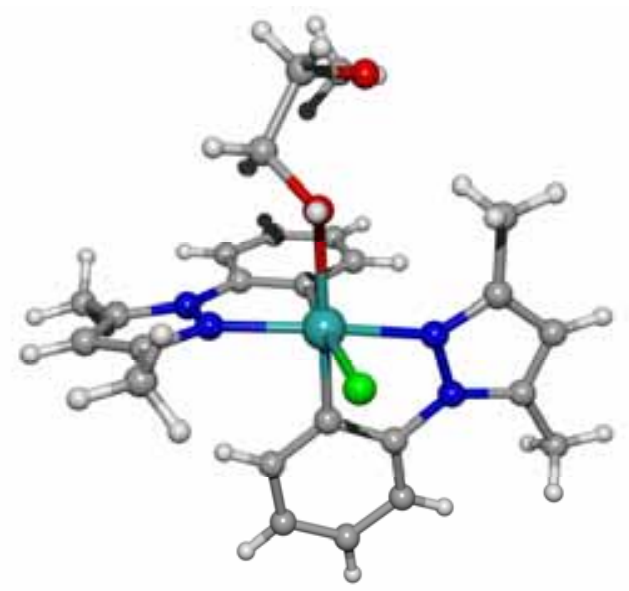

\section{Figure 2}

The metal catalysed $[2+2+2]$-cycloaddition reactions of alkynes is one of the most direct methods to generate polysubstituted benzenes, pyridines and annelated benzene derivatives. Early studies involved the use of a stoichiometric amount of the cobalt $(0)$ complex, $\mathrm{C}_{\mathrm{p}} \mathrm{Co}(\mathrm{CO})_{2}$, to promote the cyclotrimerisation. ${ }^{22} \mathrm{~A}$ wide variety of functional groups such as alkyl, aryl, vinyl, $\mathrm{CH}_{2} \mathrm{OH}, \mathrm{CO}_{2} \mathrm{R}, \mathrm{NR}_{2}, \mathrm{SR}, \mathrm{SiR}_{3}, \mathrm{~B}(\mathrm{OR})_{2}, \mathrm{Br}$ and $\mathrm{I}$ are tolerated in the process. ${ }^{23,24} \mathrm{We}$ reported that a catalytic amount of Wilkinson's catalyst, $\mathrm{RhCl}\left(\mathrm{PPh}_{3}\right)_{3}$ effects $[2+2+2]-$ cycloadditions analogous to those promoted by stoichiometric amounts of the $\mathrm{C}_{\mathrm{p}} \mathrm{Co}(\mathrm{CO})_{2}$ complex. ${ }^{25}$ Since then various other transition metal catalysts based on $\mathrm{Ni}, \mathrm{Co}, \mathrm{Pd}, \mathrm{Cr}, \mathrm{Rh}, \mathrm{Fe}$, $\mathrm{Zr}, \mathrm{Nb}$, and $\mathrm{Ir}$ have been developed for alkyne trimerisation reactions. ${ }^{26}$ Cyclometallated 
complexes of $\mathrm{Rh}(\mathrm{III}), \mathrm{Ir}(\mathrm{III})$ and $\mathrm{Ru}(\mathrm{II})$ have not, to our knowledge, been reported as precatalysts for the $[2+2+2]$-cycloaddition of alkynes. This encouraged us to evaluate complexes 2-6 for such reactions.

Initally, the 1,6-diynes $7 \mathbf{a}-\mathbf{d}^{25-27}$, were reacted individually with propargyl alcohol (5 mol eq) in ${ }^{\mathrm{t}} \mathrm{BuOH}$ at appropriate temperatures in the presence of the first generation pre catalysts $\mathbf{2 a}$ (2 mol\%), $2 \mathbf{b}(2 \mathrm{~mol} \%)$, and $\mathbf{4}(4 \mathrm{~mol} \%)$ affording the corresponding benzene derivatives 8a-d (Scheme 2, Table 1). Excess of propargyl alcohol was employed to effect reduction of the precatalysts to the active catalysts.
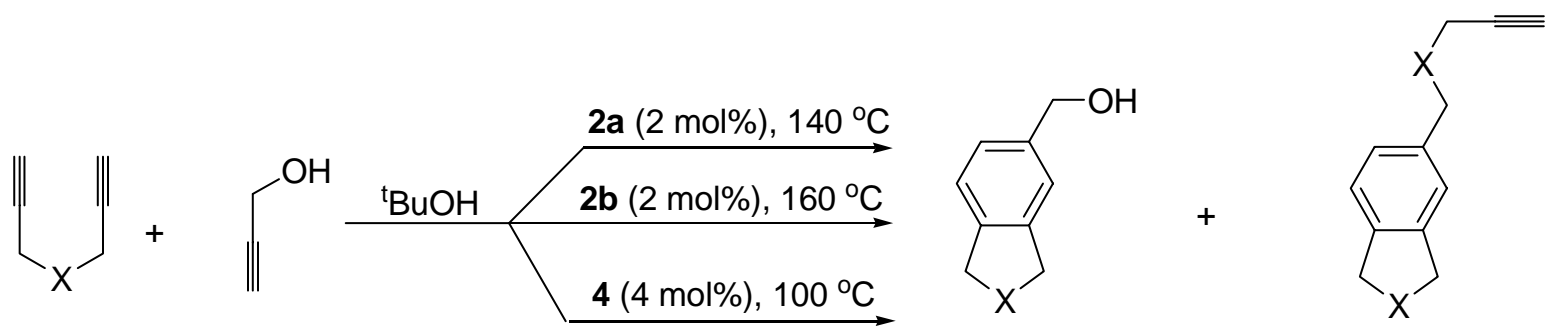
7 a. $X=0$
b. $X=\mathrm{C}\left(\mathrm{CO}_{2} \mathrm{Me}\right)_{2}$
c. $X=\mathrm{NSO}_{2} \mathrm{Ph}$
8 a. $X=0$
b. $X=\mathrm{C}\left(\mathrm{CO}_{2} \mathrm{Me}\right)_{2}$
c. $X=\mathrm{NSO}_{2} \mathrm{Ph}$

d. $X$
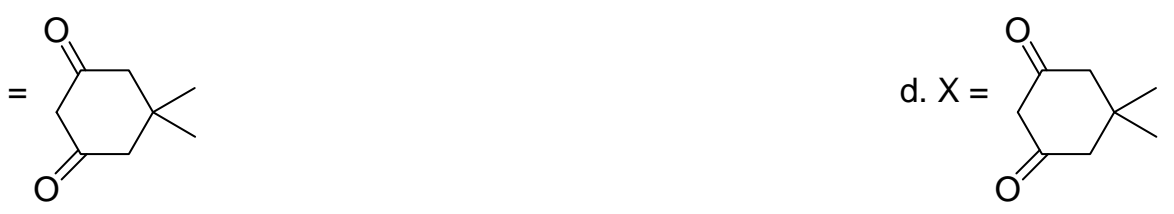

\section{Sheme 2}

Table 1. The catalytic $[2+2+2]$-cycloaddition of 1,6-diynes with propargyl alcohol

\begin{tabular}{|c|c|c|c|c|c|c|c|c|c|c|}
\hline \multirow[b]{2}{*}{ Entry } & \multirow[b]{2}{*}{ Diyne } & \multicolumn{3}{|c|}{ Catalyst $\mathbf{2 a}$} & \multicolumn{3}{|c|}{ Catalyst $\mathbf{2 b}$} & \multicolumn{3}{|c|}{ Catalyst 4} \\
\hline & & $\begin{array}{c}\text { Time } \\
(\mathrm{h})\end{array}$ & $\begin{array}{c}\text { Conv. }^{\mathrm{a}} \\
(\%)\end{array}$ & $\begin{array}{c}\text { Ratio } \\
\mathbf{8 : 9} \\
\end{array}$ & $\begin{array}{c}\text { Time } \\
(\mathrm{h})\end{array}$ & $\begin{array}{c}\text { Conv. }^{\mathrm{a}} \\
(\%)\end{array}$ & $\begin{array}{c}\text { Ratio } \\
\mathbf{8 : 9} \\
\end{array}$ & $\begin{array}{c}\text { Time } \\
\text { (h) }\end{array}$ & $\begin{array}{c}\text { Conv. }^{\mathrm{a}} \\
(\%)\end{array}$ & $\begin{array}{c}\text { Ratio } \\
\mathbf{8 : 9} \\
\end{array}$ \\
\hline 1 & $7 \mathbf{a}$ & 3 & $100(72)$ & $88: 12$ & 3 & 100 & $89: 11$ & 2.5 & 100 & $82: 18$ \\
\hline 2 & $7 \mathbf{b}$ & 3 & $67(80)$ & 100:0 & 3 & 68 & $100: 0$ & 7 & 100 & $94: 6$ \\
\hline 3 & $7 c$ & 3 & $64(65)$ & $81: 19$ & 18 & 59 & $85: 15$ & 3 & 92 & $89: 11$ \\
\hline 4 & $7 d$ & 15 & $36(83)$ & 100:0 & 36 & 39 & $100: 0$ & 15 & 100 & $87: 13$ \\
\hline
\end{tabular}

a Obtained from ${ }^{1} \mathrm{H}-\mathrm{NMR}$; Values given in brackets are the isolated yields of the major cycloadduct 9 (based on conversion)

Iridium precatalyst $\mathbf{2 b}$ requires the highest temperature $\left(160{ }^{\circ} \mathrm{C}\right)$ to promote the $[2+2+2]$ cycloaddition, whilst the $\mathrm{Rh} \mathbf{2 a}\left(140{ }^{\circ} \mathrm{C}\right)$ and $\mathrm{Ru} 4\left(100{ }^{\circ} \mathrm{C}\right)$ precatalysts, function at lower temperatures. This temperature variation reflects the relative ease, and rate, of reduction of the precatalysts to their respective lower valent active catalysts. Another interesting feature was that 
no product was observed (nmr) for 1-2 $\mathrm{h}$ indicating an induction period. Although the reaction showed high chemoselectivity for cycloadduct $\mathbf{8}$, the dimer 9, arising from the corresponding diyne, was also observed in some cases (Table 1). The diynes $\mathbf{7 b}$ and $\mathbf{7 d}$ afforded the corresponding cycloadducts exclusively in the presence of precatalysts $\mathbf{2 a}$ and $\mathbf{2 b}$, while, 6-13\% dimerisation was observed with precatalyst $\mathbf{4}$. Diyne $\mathbf{7 d}$ reacts much more slowly than diyne $\mathbf{7 b}$. Among the precatalysts evaluated for the reaction, the rate of the reaction decreased in the order $\mathrm{Ru}>\mathrm{Rh}>\mathrm{Ir}$ whilst chemoselectivity was, in general, in the reverse order.

Next we studied the [2+2+2]-cycloadditions between 1,6-diynes 7a-d and the disubstituted alkyne, 2-butyn-1,4-diol, with the first generation precatalysts $\mathbf{2 a}, \mathbf{2 b}$ and $\mathbf{4}$ (Scheme3, Table 2).

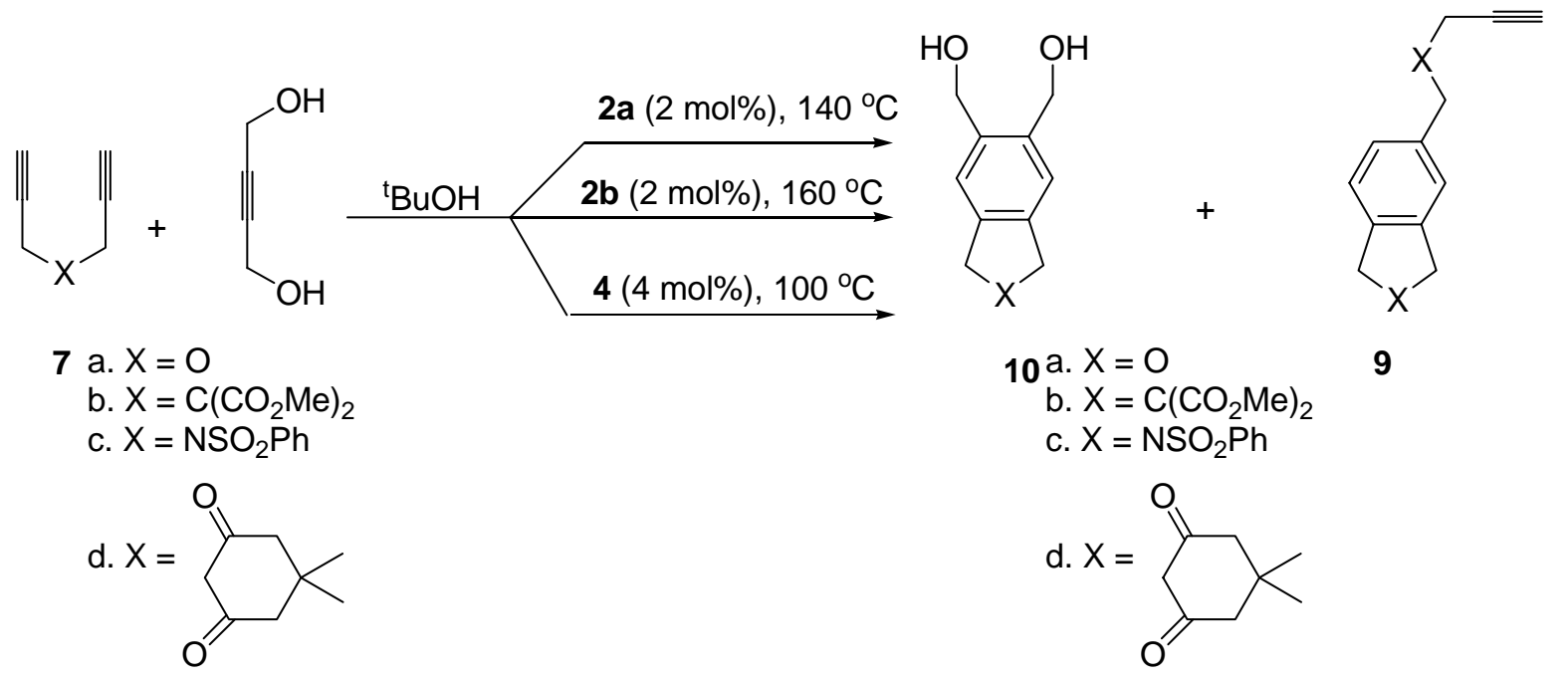

\section{Sheme 3}

Table 2. The catalytic [2+2+2]-cycloaddition of 1,6-diynes with 2-butyn-1,4-diol

\begin{tabular}{lllllllllll}
\hline & & \multicolumn{3}{c}{ Catalyst 2a } & \multicolumn{3}{c}{ Catalyst 2b } & \multicolumn{3}{c}{ Catalyst 4 } \\
\cline { 3 - 10 } Entry & Diyne & $\begin{array}{c}\text { Time } \\
\text { (h) }\end{array}$ & $\begin{array}{l}\text { Conv. } \\
\text { (\%) }\end{array}$ & $\begin{array}{l}\text { Ratio } \\
\mathbf{1 0 : 9}\end{array}$ & $\begin{array}{l}\text { Time } \\
\text { (h) }\end{array}$ & $\begin{array}{l}\text { Conv. } \\
\text { (\%) }\end{array}$ & $\begin{array}{l}\text { Ratio } \\
\mathbf{1 0 : 9}\end{array}$ & $\begin{array}{l}\text { Time } \\
\text { (h) }\end{array}$ & $\begin{array}{l}\text { Conv. }^{{ }^{a}} \\
(\%)\end{array}$ & $\begin{array}{l}\text { Ratio } \\
\mathbf{1 0 : 9}\end{array}$ \\
\hline 1 & $\mathbf{7 a}$ & 6 & $100(86)$ & $95: 5$ & 6 & 100 & $100: 0$ & 3 & 100 & $65: 35$ \\
2 & $\mathbf{7 b}$ & 4 & $98(74)$ & $95: 5$ & 3 & 100 & $100: 0$ & 16 & 76 & $57: 43$ \\
3 & $\mathbf{7 c}$ & 4 & $93(54)$ & $71: 29$ & 27 & 73 & $100: 0$ & 8 & 64 & $44: 56$ \\
4 & $\mathbf{7 d}$ & 14 & $87(65)$ & $85: 15$ & 25 & 91 & $100: 0$ & 16 & 70 & $30: 70$ \\
\hline
\end{tabular}

${ }^{a}$ Obtained from ${ }^{1} \mathrm{H}-\mathrm{NMR}$; Values given in brackets are the isolated yield of the major cycloadduct 11 (based on conversion) 
Intrestingly, in the presence of precatalysts $\mathbf{2 a}$ and $\mathbf{2 b}$ the $[2+2+2]$-cycloaddition of the 1,6diynes 7a-d with 2-butyn-1,4-diol showed an increase in the rate of the reaction compared to those reactions with propargyl alcohol under the same reaction conditions. Furthermore precatalyst $\mathbf{2 b}$ proved highly chemoselective, while precatalyst $\mathbf{4}$ showed poor chemoselectivity. This rate increase is consistent with the function of the 2-butyn-1,4-diol effecting reduction of the precatalysts to the active catalyst and in the diol case we have effectively increased the concentration of the reductant.

Next the second generation ortho-metallated Rh(III) complexes 5a, and $\mathbf{6}$ were evaluated in the $[2+2+2]$-cycloaddition of $\mathbf{7 b}$ with propargyl alcohol and 2-butyn-1,4-diol (Table 3). Results from the evaluation of precatalyst $\mathbf{2 a}$ are also included in Table 3 for comparison. When the sterically more hindered $\mathrm{Rh}(\mathrm{III})$ complex 6 was utilised in the [2+2+2]-cycloaddition of the 1,6diyne $\mathbf{7 b}$ with propargyl alcohol and 2-butyn-1,4-diol, a decrease in the reaction temperature required to effect $100 \%$ conversion and an increase in the rate of the reaction were observed compared to the reactions effected by $\mathbf{2 a}$ ( Table 3, entries 4 and 7). Note that since $\mathbf{6}$ is a monomeric complex $4 \%$ of this precatalyst was added. A possible explanation for the increased activity of the precatalyst 6 could be more facile conversion of the precatalyst 6 to the active $\mathrm{Rh}$ (I) species (discussed in the following mechanism section). $\mathrm{Rh}(\mathrm{III})$ complex $\mathbf{5 a}$ was found to be the best precatalyst among the cyclometallated complexes studied for the [2+2+2]cycloaddition of 1,6-diynes with propargyl alcohol and 2-butyn-1,4-diol (Table 3, entries 2 and 6). No diyne dimerisation product was observed in these processes except for entry 5 .

Table 3. Comparison of $\mathrm{Rh}(\mathrm{III})$ complexes for the [2+2+2-cycloaddition of 1,6-diyne $7 \mathbf{b}$ with propargyl alcohol / 2-butyn-1,4-diol

\begin{tabular}{llllll}
\hline Entry & Catalyst $^{\mathrm{a}}$ & \multicolumn{1}{c}{ Alkyne } & Time (h) & $\begin{array}{c}\text { Temp. } \\
\left({ }^{\circ} \mathrm{C}\right)\end{array}$ & $\begin{array}{c}\text { Conversion } \\
(\%)^{\mathrm{c}}\end{array}$ \\
\hline 1 & $\mathbf{2 a}$ & Propargyl alcohol & 3 & 140 & 67 \\
2 & $\mathbf{5 a}$ & Propargyl alcohol & 0.5 & 110 & 100 \\
3 & $\mathbf{6}^{\mathbf{b}}$ & Propargyl alcohol & 1 & 110 & 95 \\
4 & $\mathbf{2 a}$ & 2-butyn-1,4-diol & 4 & 140 & $98^{\mathrm{d}}$ \\
5 & $\mathbf{5 a}$ & 2-butyn-1,4-diol & 0.25 & 110 & 100 \\
6 & $\mathbf{6}^{\mathbf{b}}$ & 2-butyn-1,4-diol & 1 & 110 & 100 \\
\hline
\end{tabular}

${ }^{\mathrm{a}} 2 \mathrm{~mol} \%$ catalyst was used. ${ }^{\mathrm{b}} 4 \mathrm{~mol} \%$ catalyst was used. ${ }^{\mathrm{c}}$ obtained from ${ }^{1} \mathrm{H}-\mathrm{NMR}$ and no dimersation was observed. ${ }^{\mathrm{d}} 5 \%$ dimer was obtained.

\section{Mechanism}

In our original work with Wilkinson's catalyst, which employed a series of 1,6-diynes 8 with various tethers $\mathrm{X}$, we interpreted our results in terms of Scheme $4 .{ }^{25}$ 


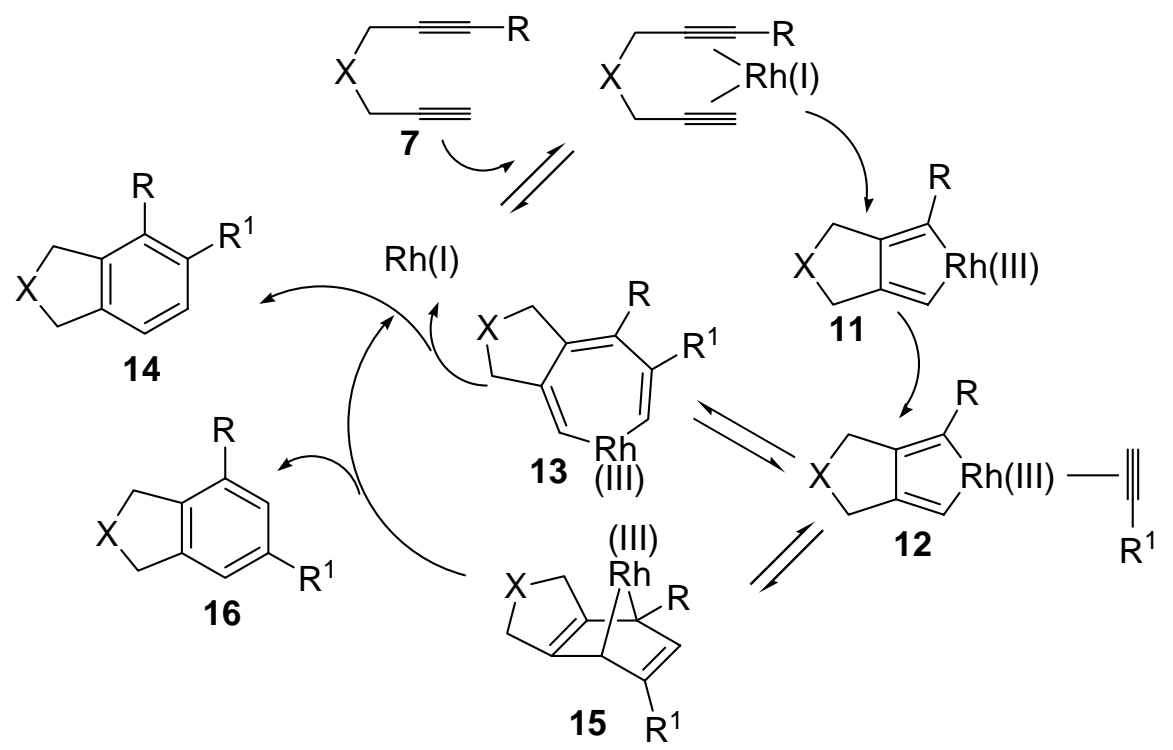

\section{Sheme 4}

Initial coordination of the rhodium(I) catalyst to the 1,6-diyne is followed by oxidative addition-cyclisation to produce the rhodacyclopentadiene complex 11. Coordination of the monoyne then gives complex 12 which undergoes either monoyne insertion to give 13 or a Diels-Alder type reaction to give 15 . Finally, reductive elimination $13 \rightarrow 14 / 15 \rightarrow 16$ gives the products and regenerates the $\mathrm{Rh}(\mathrm{I})$ catalytic species. In recent years the number of characterised metallocyclopentadienes $^{28,29}$ and metallocycloheptatrienes ${ }^{30}$ has continued to expand. The unresolved problem of whether the Diels-Alder like pathway $\mathbf{1 3} \rightarrow \mathbf{1 6}$ (Scheme 5) or the insertion pathway $\mathbf{1 2} \rightarrow \mathbf{1 3}$, or both, play a role in the [2+2+2]-cyclotrimerisation has seen some clarification. Thus crystal structures of $\mathrm{M}\left(\eta^{4}-\mathrm{C}_{6} \mathrm{H}_{6}\right)^{+}$complexes such as the fluxional triphos $\operatorname{Ir}(\mathrm{III})$ complex $17^{28 \mathrm{c}}$ are informative with respect to the Diels-Alder pathway.

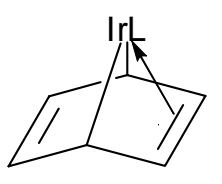

$17 \mathrm{~L}=$ triphos

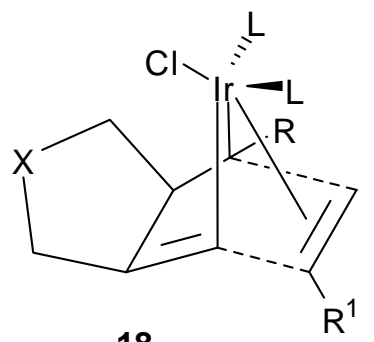

18

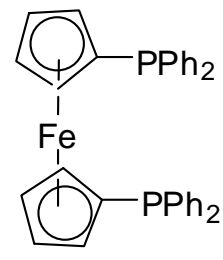

19

Very recently Takeuchi et al. ${ }^{31}$ have provided data and mechanistic arguments that both pathways may be involved, at least when $\mathrm{R}_{3} \mathrm{P}$ ligands are present, depending on steric effects and ligand dissociation rates. Their interpretation of factors favouring the Diels-Alder like sequence involves the incoming alkyne accessing a vacant apical Ir coordination site $\mathbf{1 8}$ with its 
regiochemical approach trajectory minimising steric interaction between the $\mathrm{R}$ and $\mathrm{R}^{1}$ groups in the reacting partners leading to the meta-substituted product 16 (Scheme 4). Accessing the metallocycloheptatriene pathway is believed to arise from steric hindrance in the pentacoordinate complex 20 and / or to hemilability of L favouring the equilibration $20 \rightleftharpoons 21$ in which steric interaction between $\mathrm{R} / \mathrm{R}^{1}$ is minimised. The regiochemistry of the insertion step $\mathbf{2 1} \rightarrow \mathbf{2 2}$ (Scheme 5) which leads to the ortho-substituted product 14, would then suggest that Ir-C bond formation is in advance of $\mathrm{C}-\mathrm{C}$ bond formation and that steric effects at $\mathrm{Ir}$ are the key determinant. The ferrocenyl phosphine DPPF 19 was found to be the best, of those ligands surveyed, for ortho-selectivity
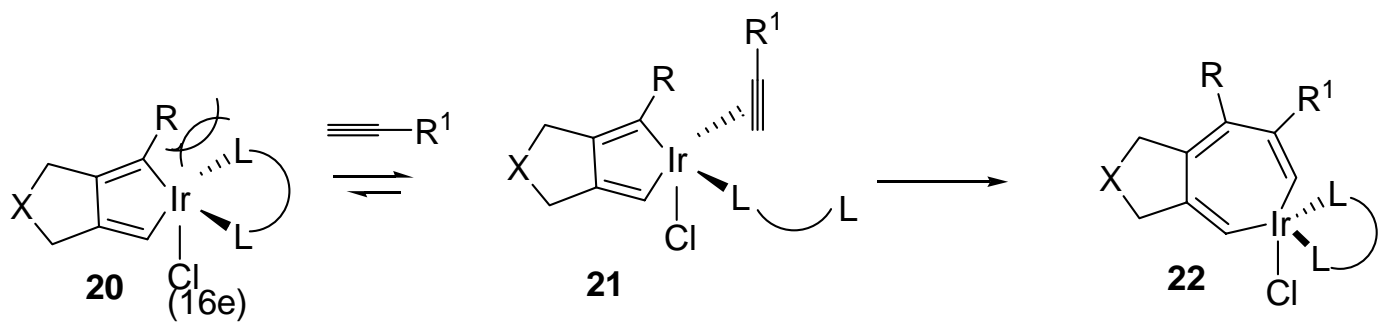

\section{Sheme 5}

The cyclometallated complexes utilised in our studies differ from those normally employed in that they are $\mathrm{M}(\mathrm{III})(\mathrm{M}=\mathrm{Ir}, \mathrm{Rh})$ complexes and lack phosphine ligands. The former require an initial reductive step, to generate the catalytically active $\mathrm{M}(\mathrm{I})$ species from the respective $\mathrm{M}(\mathrm{III})$ complexes. The $\mathrm{Ru}(\mathrm{II})$ complex $\mathbf{4}$ is assumed to undergo facile reduction to ruthenium(0) nanoparticles $^{32}$ and this accounts for the lower temperature and shorter reaction times in this case. An induction period 1-2 $\mathrm{h}$ was observed in the $[2+2+2]$-cycloaddition reactions when the first generation catalysts were used which points to a slow generation of the active catalysts. A plausible pathway for the generation of $\mathrm{M}(\mathrm{I})$ species, is shown in Scheme 6. A possible explanation for the increased activity of the second generation $\mathrm{Rh}$ precatalysts could be the rate of conversation of the $\mathrm{Rh}(\mathrm{III})$ complex to the active $\mathrm{Rh}(\mathrm{I})$ species. In the case of precatalyst 6 this conversion may be acclerated by relief of steric strain, occasioned by the bulkiness of the ligand. Thus the active catalysts $\mathbf{2 5}$ in our case differ substantially from those employed previously. They should be accessible by addition of appropriate alcohol primers and their regioselectivity remains to be explored. 


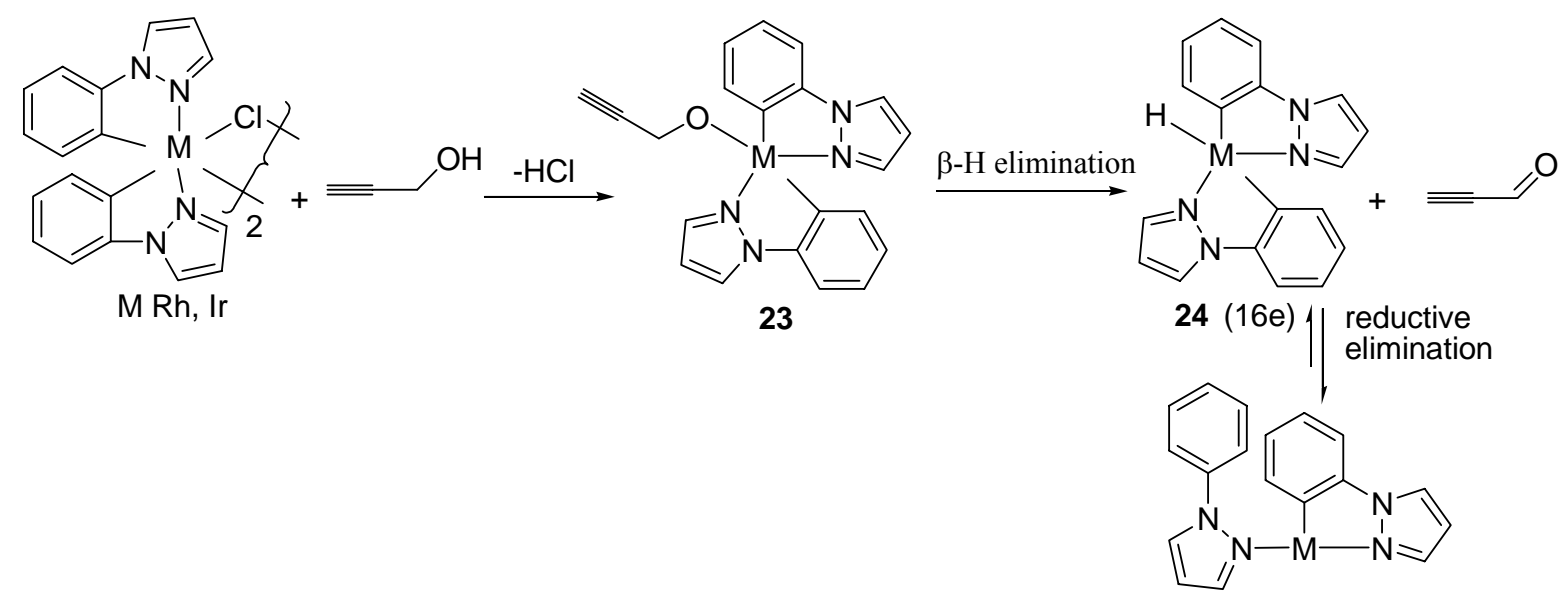

$25(14 e)$

\section{Sheme 6}

In conclusion, we report the synthesis of a variety of novel cyclometallated $\mathrm{Ir}(\mathrm{III}), \mathrm{Rh}(\mathrm{III})$ and $\mathrm{Ru}(\mathrm{II})$ complexes and their catalytic activity in the $[2+2+2]$-cycloaddition reaction between 1,6-diynes and alkynes. The Ir(III) precatalysts complex $\mathbf{2 b}$ proved highly chemoselective.

\section{Acknowledgements}

We thank Leeds University and Johnson Matthey for support.

\section{Experimental Section}

General Procedures. Melting points were determined on a Reichert hot-stage apparatus and are uncorrected. Mass spectral data were obtained from a VG Autospec instrument operating at $70 \mathrm{eV}$ (EI and FAB). The molecular ion peak $\left(\mathrm{M}^{+}\right)$refers to the $\mathrm{Ru}^{102}, \mathrm{Ir}^{193}$ or $\mathrm{Cl}^{35}$ isotope as appropriate. Accurate molecular masses were obtained from the EPSRC Swansea Mass Spectroscopy service using perfluorokerosene as an internal standard. Microanalyses were obtained using a Carbo Erba MOD11016 instrument. IR spectra were determined on a Nicolet Magna FT-IR 560 spectrometer. Nuclear magnetic resonance spectra were recorded on QE 300 and Bruker 400 instruments operating at, 300 and $400 \mathrm{MHz}$ respectively and refer to solutions in $\mathrm{CDCl}_{3}$ unless otherwise stated. Solvents were dried according to established methods, unless purchased dry from Aldrich in sure-seal bottles. The term ether refers to diethyl ether and the term petrol refers to the $40-60{ }^{\circ} \mathrm{C}$ boiling point fraction of petroleum ether. Flash column chromatography was performed over silica, Kieselgel 60 (230-400 mesh), unless otherwised 
stated. Compounds 8a-d and $\mathbf{2 a , b}$ have been previously reported. ${ }^{20,25-27}$ X-Ray data for $\mathbf{4}$ (CCDC 624678 and 6 (CCDC 628187) has been deposited in the Cambridge Crystallography Database.

\section{Cyclometallated Hg(II) $N$-phenylpyrazole complex (3)}

Utilising standard Schlenk techniques, under a dry nitrogen atmosphere, tert-butyllithium (4.85 ml, $8.2 \mathrm{mmol}, \quad 1.7 \mathrm{M}$ solution in pentane) was added slowly via a syringe to $N$ phenylpyrazole $(0.99 \mathrm{ml}, 7.5 \mathrm{mmol})$ in dry petrol $(15 \mathrm{ml})$, at room temperature. The mixture was stirred at room temperature for a further $12 \mathrm{~h}$. The yellow precipitate was collected by filtration under a dry nitrogen atmosphere, washed with dry petrol to remove tert-butyllithium and dissolved in dry tetrahydrofuran $(15 \mathrm{ml})$. Powdered mercury(II) chloride (1 .79g, $6.6 \mathrm{mmol})$ was slowly added with stirring, over the course of $30 \mathrm{~min}$ at $-77^{\circ} \mathrm{C}$. After the addition was complete, the mixture was gradually warmed to room temperature and stirred for an additional $10 \mathrm{~h}$. The resulting suspension was then filtered through celite to remove lithium chloride. The filtrate was evaporated to afford the product $(1.27 \mathrm{~g}, 51 \%)$, as pale yellow solid, which was washed with petrol and used in the next step without further purification.

$\delta_{\mathrm{H}}\left(\mathrm{DMSO}_{6}\right)$ : 7.91-7.66 (m, 3H, ArH), 7.55-7.31 (m, 3H, ArH) and $6.57(\mathrm{~m}, 1 \mathrm{H}, \mathrm{ArH}) . \mathrm{m} / \mathrm{z}$ (\%): $380\left(\mathrm{M}^{+}\left[\mathrm{Hg}^{202}\right], 39\right), 237(8), 143$ (5 1) and 77 (100).

\section{Cyclometallated Ru(II) $N$-phenylpyrazole complex (4)}

a. A suspension of di- $\mu$-chlorobis[(p-cymene)chlororuthenium(II)] $(0.93 \mathrm{~g}, 1.5 \mathrm{mmol})$ and the cyclometallated mercury(II) complex $3(1.15 \mathrm{~g}, 3 \mathrm{mmol})$ in anhydrous acetonitrile $(100 \mathrm{ml})$ was stirred at ambient temperature under a blanket of dry nitrogen for $24 \mathrm{~h}$. The solution was filtered and the filtrate evaporated on a rotary evaporator. The residue was dissolved in a minimum amount of dichloromethane and subjected to flash column chromatography over a short column of alumina, which had been packed with ether. Elution with chloroform and evaporation of the solvent under reduced pressure afford the product $(0.76 \mathrm{~g}, 61 \%)$ as shiny, brown plates, m.p. 181-184 ${ }^{\circ} \mathrm{C}$ (dec.). $\delta_{\mathrm{H}}: 8.13(\mathrm{dd}, 1 \mathrm{H}, \mathrm{J} 7.3$ and $1.2 \mathrm{~Hz}, \mathrm{ArH}), 8.05$ and $7.91(2 \mathrm{x} \mathrm{d}, 2 \mathrm{x} 1 \mathrm{H}, \mathrm{J} 2.4$ $\mathrm{Hz}, \operatorname{ArH}), 7.18-7.00$ (m, 3H, ArH), 6.47 (t, 1H, J 2.4 Hz, ArH), 5.55 (d, 2H, J 6.1 Hz, ArH), 5.28 and $5.08(2 \mathrm{x} \mathrm{d}, 2 \times 1 \mathrm{H}, \mathrm{J} 6.1 \mathrm{~Hz}, \mathrm{ArH}), 2.43\left(\mathrm{~m}, 1 \mathrm{H}, \mathrm{CHMe}_{2}\right), 2.04(\mathrm{~s}, 3 \mathrm{H}, \mathrm{Me}), 0.96$ and 0.92(2 x d, 2 x 3H, J $\left.6.9 \mathrm{~Hz}, \mathrm{CHMe}_{2}\right) . \mathrm{m} / \mathrm{z}(\%): 414\left(\mathrm{M}^{+}, 18\right), 379$ (7), 280 (24), 143 (6), 134 (26) and 119 (100). $v_{\max } / \mathrm{cm}^{-1}$ (nujol): 848 and 744. HMRS Found: $379.0741\left(\mathrm{C}_{19} \mathrm{H}_{21} \mathrm{~N}_{2} \mathrm{Ru}-\mathrm{Cl}\right.$ ) requires: 379.0743

b. $\left[\mathrm{Ru}(\mathrm{p} \text {-cymene }) \mathrm{Cl}_{2}\right]_{2}(0.1042 \mathrm{~g}, 0.17 \mathrm{mmol})$, N-phenylpyrazole $(0.0482 \mathrm{~g}, 0.33 \mathrm{mmol})$ and sodium acetate $(0.0341 \mathrm{~g}, 0.42 \mathrm{mmol})$ in DCM $(20 \mathrm{ml})$ were stirred at room temperature for 24 hThe mixture was then evaporated, leaving a brown residue, which was crystallised from DCM and hexane to afford 4 as pale brown needles in $(0.099 \mathrm{~g} 73 \%)$.

\section{General procedure for cyclometallated complexes of rhodium(III) and iridium(III)}

Either rhodium(III) chloride hydrate or iridium(III) chloride hydrate $(2.5 \mathrm{mmol})$ was added to the appropriate ligand $(6 \mathrm{mmol})$ in 2-methoxyethanol $(25 \mathrm{ml})$ and the mixture boiled under reflux 
for the appropriate time. The resulting suspension was filtered to afford the product, which was further purified by crystallisation if necessary.

Cyclometallated Rh(III) 2-phenylbenzothiazole complex (5a). Rhodium(III) chloride hydrate $(0.52 \mathrm{~g}, 2.5 \mathrm{mmol})$ and 2-phenylbenzothiazole $(1.27 \mathrm{~g}, 6 \mathrm{mmol})$ were mixed in 2-methoxyethanol $(25 \mathrm{ml})$ and heated at $125{ }^{\circ} \mathrm{C}$ ) under reflux for $16 \mathrm{~h}$. The precipitated product was filtered and washed with ether followed by $n$-hexane to afford the product $(1.08 \mathrm{~g}, 77 \%)$ as a yellow powder, m.p. $>230{ }^{\circ} \mathrm{C}$.

Found: C, 55.70; H,2.75; Cl, 6.4 50; N,5.15; $\mathrm{C}_{52} \mathrm{H}_{32} \mathrm{Cl}_{2} \mathrm{~N}_{4} \mathrm{Rh}_{2} \mathrm{~S}_{4}$ requires: $\mathrm{C}, 55.87 ; \mathrm{H}, 2.89 ; \mathrm{Cl}$, 6.34; N, 5.01\%. $\delta_{\mathrm{H}}\left(\mathrm{DMSO}_{6}\right)$ : $9.4(\mathrm{br}, 2 \mathrm{H}), 8.21(\mathrm{~d}, 2 \mathrm{H}, \mathrm{J} 7.4 \mathrm{~Hz}, \mathrm{ArH}), 7.66-7.47$ (m, 6H, ArH), 6.85 and $6.68(2 \times$ t, 2 x 2H, J 7.4 Hz, ArH) and 6.08 (d, 2H, J 7.4 Hz, ArH). m/z (\%) (FAB): 558 ( $\mathrm{M}^{+}$monomer], 1), 523 (1), 348 (1), 210 (1) and 157 (100).

Cyclometallated Ir(III) complex 2-phenylbenzothiazole (5b). Iridium(III) chloride hydrate $(0.75 \mathrm{~g}, 2.5 \mathrm{mmol})$ and 2-phenylbenzothiazole $(1.27 \mathrm{~g}, 6 \mathrm{mmol})$ were mixed in 2-methoxyethanol $(25 \mathrm{ml})$ and heated at $125{ }^{\circ} \mathrm{C}$ under reflux for $16 \mathrm{~h}$. The precipitated product was filtered and washed with ether to afford the product ( $1.3 \mathrm{~g}, 86 \%$ ), as an orange powder, m.p. $>230{ }^{\circ} \mathrm{C}$.

Found: C, 47.30; H, 2.55; Cl, 5.80; N, 4.25; $\mathrm{C}_{52} \mathrm{H}_{32} \mathrm{Cl}_{2} \mathrm{Ir}_{2} \mathrm{~N}_{4} \mathrm{~S}_{4} .1 \mathrm{M} \mathrm{H} \mathrm{H}_{2} \mathrm{O}$ requires: C,47.51; $\mathrm{H}$, $2.61 ; \mathrm{Cl}, 5.40 ; \mathrm{N}, 4.26 \%$. $\delta_{\mathrm{H}}\left(\mathrm{DMSO}_{6}\right): 8.24$ (d, 4H, J $\left.7.5 \mathrm{~Hz}, \mathrm{ArH}\right), 8.1$ 1-8.00 (m, 4H, ArH), 7.70-7.50 (m, 16H, ArH), 6.83 and 6.62 ( 2 x brs, 2 x 4H, ArH). m/z (\%), (FAB): 648(M ${ }^{+}$ monomer, 1), 613 (3), 438 (1), 232 (100) and 210 (1). $v_{\max } / \mathrm{cm}^{-1}$ (nujol): 1579, 752 and 739.

Cyclometallated Rh(III) 3,5-dimethyl-2-phenylpyrazole complex (6). Rhodium(III) chloride hydrate $(1.05 \mathrm{~g}, 5 \mathrm{mmol})$ and 3,5-dimethyl-2-phenylpyrazole $(2.06 \mathrm{~g}, 12 \mathrm{mmol})$ were mixed in 2methoxyethanol $(50 \mathrm{~m} 1)$ and heated at $125{ }^{\circ} \mathrm{C}$ under reflux for $24 \mathrm{~h}$. On cooling to room temperature, the product, $(1.25 \mathrm{~g}, 45 \%)$, crystallised from the reaction mixture as colourless needles, m.p. $>230^{\circ} \mathrm{C}$.

Found: C, 53.75; H, 5.40; N, 9.95; Cl, 6.30; $\mathrm{C}_{22} \mathrm{H}_{22} \mathrm{C}_{1} \mathrm{~N}_{4} \mathrm{Rh}_{.} \mathrm{C}_{3} \mathrm{H}_{8} \mathrm{O}_{2}$ requires: C, 53.90; $\mathrm{H}, 5.45$; $\mathrm{N}, 10.05 ; \mathrm{Cl}, 6.35 \% . \delta_{\mathrm{H}} 7.22(\mathrm{~d}, 2 \mathrm{H}, \mathrm{J} 7.3 \mathrm{~Hz}, \mathrm{ArH}), 6.83$ and 6.60 (2 x t, 2 x 2H, J 7.3Hz, ArH), 6.20 (d, 2H, J 7.3 Hz, ArH), 6.07 (s, 2H, ArH), 3.75-3.70 (m, 2H, OCH $), 3.50$ (t, 2H, J 4.5Hz, $\left.\mathrm{OCH}_{2}\right), 3.39$ (s, 3H, OMe), $2.72(\mathrm{~s}, 6 \mathrm{H}, 2 \mathrm{xMe}), 2.32$ (brs, 6H, 2xMe) and 1.96 (t, 1H, J 6.1Hz, $\mathrm{OH}) . \mathrm{m} / \mathrm{z}(\%),(\mathrm{FAB}): 480\left(\mathrm{M}^{+}-\mathrm{C}_{3} \mathrm{H}_{8} \mathrm{O}_{2}, 13\right), 445$ (100), 309 (4) and $171(1) \cdot v_{\max } / \mathrm{cm}^{-1}$ (nujol): 3286, 1111. 1045 and 748 .

\section{General procedure for cyclisation of 1,6-diynes with monoynes}

1,6-Diyne, monoyne and the catalyst were mixed in tert-butanol in a Schlenk tube and stirred and heated at the appropriate temperature for the appropriate time. The solvent was then removed under reduced pressure and the residue was purified by flash column chromatography to afford the product.

\section{(1,3-Dihydro-2-benzofuran-5-yl)methanol (8a)}

2,2-Diprop-2 -ynylether $(0.024 \mathrm{~g}, 0.25 \mathrm{mmol})$, propargyl alcohol $(73 \mu \mathrm{l}, 1.25 \mathrm{mmol})$ and $2 \mathrm{a}$ 
(4.6 mg, $0.005 \mathrm{mmol})$ were mixed in tert-butanol $(7 \mathrm{ml})$ and stirred at $140{ }^{\circ} \mathrm{C}$ for $3 \mathrm{~h}$. After removing the solvent the residue was purified by flash column chromatography, eluting with 1:4 $\mathrm{v} / \mathrm{v}$ ether-petrol to afford the product $(0.027 \mathrm{~g}, 72 \%$ based on $100 \%$ conversion) as a white powder, m.p. $68-70^{\circ} \mathrm{C}\left(\right.$ Lit. $\left.^{25} 70-71{ }^{\circ} \mathrm{C}\right)$.

$\delta_{\mathrm{H}}$ : 7.24-7.21 (m, 3H, $\left.\mathrm{ArH}\right), 5.11\left(\mathrm{~s}, 4 \mathrm{H}, 2 \mathrm{x} \mathrm{CH}_{2}\right)$ and $4.71\left(\mathrm{~s}, 2 \mathrm{H}, \mathrm{CH}_{2} \mathrm{OH}\right) . \mathrm{m} / \mathrm{z}(\%): 150\left(\mathrm{M}^{+}\right.$, 67), $133(5), 119(32)$ and $91(100){ }^{25}$

Catalyst (2b). $(5.1 \mathrm{mg}, 0.005 \mathrm{mmol})$ heating at $160{ }^{\circ} \mathrm{C}$ for $3 \mathrm{~h}$ gave the product $89 \%$

Catalyst (4). $\left(4.1 \mathrm{mg}, 0.01 \mathrm{mmol}\right.$ ) heating at $100{ }^{\circ} \mathrm{C}$ for $2.5 \mathrm{~h}$ gave the product $82 \%$

\section{Dimethyl 5-hydroxymethyl-1,3-dihydro-2H-indene-2,2-dicarboxylate (8b)}

A mixture of dimethyl 2,2-diprop-2'-ynylmalonate $(0.05 \mathrm{~g}, 0.25 \mathrm{mmol})$, propargyl alcohol $(73 \mu \mathrm{l}$, $1.25 \mathrm{mmol})$ and $2 \mathrm{a}(4.6 \mathrm{mg}, 0.005 \mathrm{mmol})$ in tert-butanol $(7 \mathrm{ml})$ was stirred and heated at $140{ }^{\circ} \mathrm{C}$ for $3 \mathrm{~h}$. After removing the solvent, the residue was purified by flash column chromatography, eluting with $1: 1 \mathrm{v} / \mathrm{v}$ ether-petrol to afford the product $(0.07 \mathrm{~g}$. $80 \%$ based on $67 \%$ conversion $)$ as a colourless, thick oil.

Found: $\mathrm{C}, 63.35 ; \mathrm{H}, 6.20 ; \mathrm{C}_{14} \mathrm{H}_{16} \mathrm{O}_{5}$ requires: $\mathrm{C}, 63.65 ; \mathrm{H}, 6.10 \% . \delta_{\mathrm{H}} 7.20-7.15(\mathrm{~m}, 3 \mathrm{H}, \mathrm{ArH})$, $4.61\left(\mathrm{~s}, 2 \mathrm{H}, \mathrm{CH}_{2} \mathrm{OH}\right), 3.73$ (s, $\left.6 \mathrm{H}, 2 \times \mathrm{CO}_{2} \mathrm{Me}\right)$ and 3.57 (s, $\left.4 \mathrm{H}, 2 \times \mathrm{CH}_{2}\right) . \mathrm{m} / \mathrm{z}(\%): 264\left(\mathrm{M}^{+}, 37\right)$, 233 (7), 205 (50), 204 (100) and 59 (46). $v_{\max } / \mathrm{cm}^{-1}$ (nujol): 3514, 1753, 1724, 1281, 1077 and 1046.

Catalyst (2b). $(5.1 \mathrm{mg}, 0.005 \mathrm{mmol})$ heating at $160{ }^{\circ} \mathrm{C}$ for $3 \mathrm{~h}$ gave $68 \%$ of product based on $68 \%$ conversion.

Catalyst (4). ( $4.1 \mathrm{mg}, 0.001 \mathrm{mmol}$ ) heating at $100{ }^{\circ} \mathrm{C}$ for $7 \mathrm{~h}$ gave the product $94 \%$

Catalyst (5a). $(5.6 \mathrm{mg}, 0.005 \mathrm{mmol})$ heating at $110{ }^{\circ} \mathrm{C}$ for $30 \mathrm{~min}$ gave the product in quantitative yield.

Catalyst (6). ( $9.6 \mathrm{mg}, 0.01 \mathrm{mmol}$ ) heating at $110{ }^{\circ} \mathrm{C}$ for $1 \mathrm{~h}$ gave $95 \%$ of product based on $95 \%$ conversion.

\section{( $N$-Phenylsulfonyl-2,3-dihydro-1H-isoindol-5-yl)methanol (8c)}

$N, N$-Diprop-2-ynylphenylsulphonamide $(0.058 \mathrm{~g}, 0.25 \mathrm{mmol})$, propargyl alcohol $(73 \mu \mathrm{l}$, $1.25 \mathrm{mmol})$ and catalyst $2 \mathrm{a}(4.6 \mathrm{mg}, 0.005 \mathrm{mmol})$ were mixed in tert-butanol $(7 \mathrm{ml})$ and stirred at $140{ }^{\circ} \mathrm{C}$ for $3 \mathrm{~h}$. After removing the solvent, the residue was purified by flash column chromatography, eluting with $3: 1 \mathrm{v} / \mathrm{v}$ ether-ethyl acetate, followed by crystallisation from ether and dichloromethane (trace) to afford the product $(0.03 \mathrm{~g}, 66 \%$ based on $64 \%$ conversion) as a white powder, m.p. $97-99^{\circ} \mathrm{C}$.

Found: $\mathrm{C}, 58.70 ; \mathrm{H}, 5.20 ; \mathrm{N}, 5.00 ; \mathrm{C}_{15} \mathrm{H}_{15} \mathrm{NO}_{3} \mathrm{~S}$ requires: $\mathrm{C}, 62.26 ; \mathrm{H}, 5.23 ; \mathrm{N}, 4.84 \%$. $\delta_{\mathrm{H}} 7.88-$ $7.84(\mathrm{~m}, 2 \mathrm{H}, \mathrm{ArH}), 7.57-7.47$ and 7.25-7.11(2 x m, $2 \times 3 \mathrm{H}, \mathrm{ArH}), 4.64\left(\mathrm{~s}, 2 \mathrm{H}, \mathrm{CH}_{2} \mathrm{OH}\right)$ and 4.59 (s, 4H, $\left.2 \times \mathrm{CH}_{2}\right) . \mathrm{m} / \mathrm{z}(\%): 289\left(\mathrm{M}^{+}, 21\right), 148$ (100), 141 (21), 77 (88) and 51 (37).

Catalyst (2b). $\left(5.1 \mathrm{mg}, 0.005 \mathrm{mmol}\right.$ ) heating at $160{ }^{\circ} \mathrm{C}$ for $18 \mathrm{~h}$ gave the product $50 \%$ based on $59 \%$ conversion.

Catalyst (4). $(4.1 \mathrm{mg}, 0.01 \mathrm{mmol})$ heating at $100{ }^{\circ} \mathrm{C}$ for $3 \mathrm{~h}$ gave the product $82 \%$ based on $92 \%$ conversion. 


\section{( $N$-Benzenesulfonyl-2,3-dihydro-1H-isoindol-5yl)-methanol (8d)}

2,2-Diprop-2 -ynyldimedone $(0.054 \mathrm{~g}, 0.25 \mathrm{mmol})$, propargyl alcohol $(73 \mu \mathrm{l}, 1.25 \mathrm{mmol})$ and catalyst $2 \mathrm{a}(4.6 \mathrm{mg}, 0.005 \mathrm{mmol})$ were mixed in tert-butanol $(7 \mathrm{ml})$ and stirred at $140{ }^{\circ} \mathrm{C}$ for $15 \mathrm{~h}$. After removing the solvent, the residue was purified by flash column chromatography, eluting with ether to afford the product $(0.02 \mathrm{~g}, 83 \%$ based on $36 \%$ conversion) as a white powder, m.p. $157-159{ }^{\circ} \mathrm{C}$ (Lit. $\left.{ }^{25} 158-159{ }^{\circ} \mathrm{C}\right)$.

$\delta_{\mathrm{H}}$ 7.18-7.14 (s, 3H, ArH), 4.63 (d, 2H, J $\left.5.3 \mathrm{~Hz}, \mathrm{CH}_{2} \mathrm{OH}\right), 3.44$ (s, 4H, 2 x CH CH$_{2}, 2.70$ (s, 4H, 2 x $\left.\mathrm{CH}_{2} \mathrm{CO}\right)$ and 1.04 (s, 6H, 2 x Me). m/z (\%): $272\left(\mathrm{M}^{+}, 7\right), 255$ (4), 188 (34) and 115 (38).

Catalyst (2b). ( $5.1 \mathrm{mg}, 0.005 \mathrm{mmol})$ heating at $160{ }^{\circ} \mathrm{C}$ for $36 \mathrm{~h}$ gave the product $39 \%$ based on $39 \%$ conversion.

Catalyst (4). (4.1 mg, $0.01 \mathrm{mmol}$ ) heating at $100{ }^{\circ} \mathrm{C}$ for $15 \mathrm{~h}$ gave the product $89 \%$.

\section{(6-Hydroxymethyl-1,3-dihydro-2-benzofuran-5-yl)methanol (10a)}

Diprop-2-ynylether $(0.024 \mathrm{~g}, 0.25 \mathrm{mmol}), 2$-butyn-1,4-diol $(0.065 \mathrm{~g}, 0.75 \mathrm{mmol})$ and the catalyst 2a (4.6 mg, $0.005 \mathrm{mmol})$ were mixed in tert-butanol $(7 \mathrm{ml})$ and stirred at $140{ }^{\circ} \mathrm{C}$ for $6 \mathrm{~h}$. After removing the solvent, the residue was purified by flash column chromatography, eluting with ether to afford the product $(0.039 \mathrm{~g}, 86 \%)$ as a pale yellow, thick gum.

Found: $\mathrm{C}, 66.35 ; \mathrm{H}, 6.50 ; \mathrm{C}_{10} \mathrm{H}_{12} \mathrm{O}_{3}$ requires: $\mathrm{C}, 66.65 ; \mathrm{H}, 6.71 \% . \delta_{\mathrm{H}}: 7.21(\mathrm{~s}, 2 \mathrm{H}, \mathrm{ArH}), 5.05(\mathrm{~s}$, 4H, $2 \times \mathrm{CH}_{2}$ ), 4.71 (s, 4H, $\left.2 \times \mathrm{CH}_{2} \mathrm{OH}\right)$ and 3.37 (brs, 2H, $\left.2 \times \mathrm{OH}\right) . \mathrm{m} / \mathrm{z}(\%): 180\left(\mathrm{M}^{+}, 1\right), 163$ (12), 149 (16) and 57 (100). $v_{\max } / \mathrm{cm}^{-1}$ (nujol): 3272, 1181 and 1073.

Catalyst (2b). $(5.1 \mathrm{mg}, 0.005 \mathrm{mmol})$ heating at $160{ }^{\circ} \mathrm{C}$ for $6 \mathrm{~h}$ gave the product in quantitative yield

Catalyst (4). (4.1 mg, $0.01 \mathrm{mmol}$ ) heating at $100{ }^{\circ} \mathrm{C}$ for $3 \mathrm{~h}$ gave the product $65 \%$.

\section{Dimethyl 5,6-bis(hydroxymethyl)-1,3-dihydro-2H-indene-2,2-dicarboxylate (10b)}

Dimethyl 2,2-diprop-2 -ynylmalonate $(0.05 \mathrm{~g}, 0.25 \mathrm{mmol}), 2$-butyn- 1 ,4-diol (0.065g, $0.75 \mathrm{mmol})$ and catalyst $2 \mathrm{a}(4.6 \mathrm{mg}, 0.005 \mathrm{mmol})$ were mixed in tert-butanol $(7 \mathrm{ml})$ and stirred at $140{ }^{\circ} \mathrm{C}$ for $4 \mathrm{~h}$. After removing the solvent, the residue was purified by flash column chromatography, eluting with ether to afford the product $(0.053 \mathrm{~g}, 74 \%$ based on $98 \%$ conversion) as a pale yellow gum.

Found: $\mathrm{C}, 60.95 ; \mathrm{H}, 6.50 ; \mathrm{C}_{15} \mathrm{H}_{18} \mathrm{O}_{6}$ requires: $\mathrm{C}, 61.22 ; \mathrm{H}, 6.16 \%$. $\delta_{\mathrm{H}}$ : $7.14(\mathrm{~s}, 2 \mathrm{H}, \mathrm{ArH}), 4.59(\mathrm{~d}$, $\left.4 \mathrm{H}, \mathrm{J} 4.3 \mathrm{~Hz}, 2 \times \mathrm{CH}_{2} \mathrm{OH}\right), 3.72\left(\mathrm{~s}, 6 \mathrm{H}, 2 \times \mathrm{CO}_{2} \mathrm{Me}\right)$ and $3.55\left(\mathrm{~s}, 4 \mathrm{H}, 2 \times \mathrm{CH}_{2}\right) . \mathrm{m} / \mathrm{z}(\%): 294$ $\left(\mathrm{M}^{+}, 14\right), 277(20), 263(9), 235$ (38), $216(100)$ and $59(53)$.

Catalyst (2b). $(5.1 \mathrm{mg}, 0.005 \mathrm{mmol})$ heating at $160{ }^{\circ} \mathrm{C}$ for $3 \mathrm{~h}$ gave the product in quantitative yield.

Catalyst (4) $(4.1 \mathrm{mg}, 0.01 \mathrm{mmoI})$ heating at $100{ }^{\circ} \mathrm{C}$ for $16 \mathrm{~h}$ gave the product $43 \%$ based on $76 \%$ conversion.

Catalyst (5a). (5.6mg, $0.005 \mathrm{mmol}$ ) heating at $110{ }^{\circ} \mathrm{C}$ for $15 \mathrm{~min}$ gave the product in quantitative yield

Catalyst (6). $(9.6 \mathrm{mg}, 0.01 \mathrm{mmoI})$ heating at $110^{\circ} \mathrm{C}$ for $1 \mathrm{~h}$ gave the product in quantitative yield. 


\section{( $N$-Benzenesulfonyl-6-hydroxymethyl-2,3-dihydro-1H-isoindol-5-yl)methanol (10c)}

$N, N$-Diprop-2-ynylphenylsulphonamide $(0.058 \mathrm{~g}, 0.25 \mathrm{mmol}), 2$-butyn-1,4-diol $(0.065 \mathrm{~g}, 0.75$ $\mathrm{mmol})$ and catalyst $2 \mathrm{a}(4.6 \mathrm{mg}, 0.005 \mathrm{mmol})$ were mixed in tert-butanol $(7 \mathrm{ml})$ and stirred at $140{ }^{\circ} \mathrm{C}$ for $4 \mathrm{~h}$. After removing the solvent, the residue was purified by flash column chromatography, eluting with $1: 1 \mathrm{v} / \mathrm{v}$ ether-ethyl acetate, followed by crystallisation from dichloromethane to afford the product $(0.04 \mathrm{~g}, 54 \%$ based on $93 \%$ conversion) as a pale yellow powder, m.p. $109-112^{\circ} \mathrm{C}$.

Found: C,59.90; H, 5.45; N, $4.20 \mathrm{C}_{16} \mathrm{H}_{17} \mathrm{NO}_{4} \mathrm{~S}$ requires: $\mathrm{C}, 60.17 ; \mathrm{H}, 5.37 ; \mathrm{N}, 4.39 \%$. $\delta_{\mathrm{H}}$ 7.897.85 (m, 2H, ArH), 7.58-7.48 (m, 3H, ArH), 7.17 (s, 2H, ArH), 4.68 (s, 4H, $\left.2 \mathrm{x} \mathrm{CH}_{2} \mathrm{OH}\right), 4.59$ (s, $\left.4 \mathrm{H}, 2 \times \mathrm{CH}_{2}\right)$ and $4.28(\mathrm{~s}, 2 \mathrm{H}, 2 \times \mathrm{OH}) \cdot \mathrm{m} / \mathrm{z}(\%): 319\left(\mathrm{M}^{+}, 15\right), 302$ (9), 288 (5), 141 (27), 77 (100) and 51 (46). $v_{\max } / \mathrm{cm}^{-1}$ (nujol): 3299, 1343, 1162, 758 and 689.

Catalyst (2b). $(5.1 \mathrm{mg}, 0.005 \mathrm{mmol})$ heating at $160{ }^{\circ} \mathrm{C}$ for $27 \mathrm{~h}$ gave the product $73 \%$ based on $73 \%$ conversion.

Catalyst (4). (4.1 mg, $0.01 \mathrm{mmol}$ ) heating at $100{ }^{\circ} \mathrm{C}$ for $8 \mathrm{~h}$ gave the product $28 \%$ based on $64 \%$ conversion.

5',6'-Bis(hydroxymethyl)-4,4-dimethyl-1'3'-dihydro-2H,^H-spiro[cyclohexane-1,2'-indene]2,6-dione (10d)

2,2-Diprop-2'-ynyldimedone (0.054g, $0.25 \mathrm{mmol}), 2$-butyn-1,4-diol $(0.065 \mathrm{~g}, 0.75 \mathrm{mmol})$ and catalyst $2 \mathrm{a}(4.6 \mathrm{mg}, 0.005 \mathrm{mmol})$ were mixed in tert-butanol $(7 \mathrm{ml})$ and stirred at $140{ }^{\circ} \mathrm{C}$ for $14 \mathrm{~h}$. After removing the solvent, the residue was purified by flash column chromatography, eluting with $4: 1 \mathrm{v} / \mathrm{v}$ ether-ethyl acetate to afford the product $(0.042 \mathrm{~g}, 65 \%$ based on $87 \%$ conversion) as a white powder, m.p. $142-145^{\circ} \mathrm{C}$.

Found: C, 71.25; H, 7.55; $\mathrm{C}_{18} \mathrm{H}_{22} \mathrm{O}_{4}$ requires: $\mathrm{C}, 71.50 ; \mathrm{H}, 7.33 \%$. $\delta_{\mathrm{H}} 7.15(\mathrm{~s}, 2 \mathrm{H}, \mathrm{ArH}), 4.66(\mathrm{~s}$, 4H, $2 \times \mathrm{CH}_{2} \mathrm{OH}$ ), 3.43 (s, 4H, $2 \times \mathrm{CH}_{2}$ ), 2.91 (brs, $\left.2 \mathrm{H}, 2 \times \mathrm{OH}\right), 2.70$ (s, 4H, $2 \times \mathrm{CH}_{2} \mathrm{CO}$ ) and 1.04 (s, 6H, $2 \times \mathrm{Me}) \cdot \mathrm{m} / \mathrm{z}(\%): 302\left(\mathrm{M}^{+}, 14\right), 285(5), 218(100), 128(46)$ and $115(38) \cdot v_{\max } / \mathrm{cm}^{-1}$ (nujol): 3468,1724 and 1071.

Catalyst (2b). $(5.1 \mathrm{mg}, 0.005 \mathrm{mmol})$ heating at $160{ }^{\circ} \mathrm{C}$ for $25 \mathrm{~h}$ gave the product $91 \%$ based on $91 \%$ conversion.

Catalyst (4). (4.1 mg, $0.01 \mathrm{mmol})$ heating at $100{ }^{\circ} \mathrm{C}$ for $16 \mathrm{~h}$ gave the product $21 \%$ based on $70 \%$ conversion.

\section{References}

1. Herrmann, W. A.; Brossmer, K.; Oefele, C. P.; Reisinger, J. Angew. Chem. Int. Ed. 1995, 34, 1844.

2. (a) Albisson, D. A.; Bedford, R. B.; Lawrence, S. E.; Scully, P. N. Chem. Commun. 1998, 2095. (b) Bedford, R. B.; Limmert, M. E.; Hazelwood, S. L. Chem. Commun. 2002, 2610. (c) Bedford, R. B.; Hazelwood, S. L.; Albisson, D. A. Organometallics 2002, 21, 2599. (d) 
Bedford, R. B.; Cazin, C. S. J.; Hazelwood, S. L. Angew. Chem. Int. Ed. 2002, 41, 4120.

3. Palencia, H.; Garcia-Jimenez, F.; Takacs, J. M. Tetrahedron Lett. 2004, 45, 3849.

4. (a) Ohff, M.; Ohff, A.; Milstein, D. Chem. Commun. 1999, 357. (b) Weissman, H.; Milstein, D.; Chem. Commun. 1999, 1901. (c) Wu, Y.; Hou, J.; Yun, H.; Cui, X.; Yuan, R. J. Organomet. Chem. 2001, 637, 793. (d) Rocaboy, C.; Gladysz, J. A. Tetrahedron 2002, 58, 4007.

5. (a) Gai, X.; Grigg, R.; Ramzan, M. I.; Sridharan, V.; Collard, S.; Muir, J. E. Chem. Commun. 2000, 1765. (b) Evans, P.; Hogg, P.; Grigg, R.; Nurnabi, M.; Hinsley, J.; Sridharan, V.; Suganthan, S.; Korn, S.; Collard, S.; Muir, J. E. Tetrahedron 2005, 61, 9696.

6. (a) Gruber, A. S.; Zim, D.; Ebeling, G.; Monteiro, A. L.; Dupont, J. J. Org. Lett. 2000, 2, 1287. (b) Munoz, M. P.; Martin-Matute, B.; Fernandez-Rivas, C.; Cardenas, D. J.; Echavarren, A. M. Adv. Synth. Catal. 2001, 343, 338.

7. (a) Iyer, S.; Ramesh, C. Tetrahedron Lett. 2000, 41, 8981. (b) Iyer, S.; Jayanthi, A. Tetrahedron Lett. 2001, 42, 7877. (c) Alonso, D. A.; Najera, C.; Pacheco, C. Adv. Synth. Catal. 2002, 344, 172.

8. (a) Bedford, R. B. Chem. Commun. 2003, 1787. (b) Bedford, R. B.; Cazin, C. S. J.; Holder, D. Coord. Chem. Rev. 2004, 248, 995.

9. Dupont, J.; Crestina, C.; Spencer, J. Chem. Rev. 2005, 105, 2527.

10. (a) Longmire, J. M.; Zhang, X.; Shang, M. Organometallics 1998, 17, 4374. (b) Albrecht, M.; Kocks, B. M.; Spek, A.L.; van Koten, G. J. Organomet. Chem. 2001, 624, 271.

11. (a) Stark, M. A.; Jones, C. J.; Richards, C. J. Organometallics 2000, 19, 1282. (b) Takenaka, K.; Uozumi, Y. Org. Lett. 2004, 6, 1883.

12. Denmark S. E.; Stavenger, R. A.; Faucher, A. M.; Edwards, J. P. J. Org. Chem. 1997, 62, 3375.

13. (a) Taber, D. F.; Malcolm, S. C. J. Am. Chem. Soc. 1999, 121, 860. Gerisch, M.; Krumper, J. R.; Bergman, R. G.; Tilley, T. D. J. Am. Chem. Soc. 2001, 123, 5818.

14. (a) Leitner, A.; Shekhar, S.; Pouy, M. J.; Hartwig, J. F. J. Am. Chem. Soc. 2005, 127, 15506. (b) Nishihara, Y.; Yoda, C.; Itazaki, M.; Osakada, K. Bull. Chem. Soc. Jpan. 2005, 78, 1469.

15. (a) Davies,D. L.; Al-Duaij, O.; Fawcett, J.; Giardiello, M.; Hilton, S. T.; Russel, D. R. J. Chem. Soc. Dalton Trans. 2003, 4132. (b) Dorta, P.; Stevens, E. D.; Nolan, S. P. J. Am. Chem. Soc. 2004, 126, 5054. (c) Lal Pratihar, J.; Maiti, N.; Chattopadhyay, S. Inorg. Chem. 2005, 44, 6111. (c) Lal Partihar, J.; Patra, D.; Chattopadhyay, S. J. Organomet. Chem. 2005, $690,4816$.

16. (a) Garbauskas, M. F. ; Kasper, J. S.; Lewis, L. N. J. Organomet. Chem. 1984, 276, 241. (b) Lewis, L. N.; Smith, J. F. J. Am. Chem. Soc. 1986, 108, 2728. (c) Bedford, R. B.; Castillon, S.; Chaloner, P. A.; Claver, C.; Fernandez, E.; Hitchcock, P. B.; Ruiz, A. Organometallics 1996, 15, 3990. (d) Baratta, W.; Da Ros, P.; Del Zotto, A.; Sechi, A.; Zangrando, E.; Rigo, P. Angew. Chem. Int. Ed. 2004, 43, 3584.

17. (a) Motoyama, Y.; Narusawa, H.; Nishiyama, H. Chem. Commun. 1999, 131.

18. (a) Maestri, M.; Balzani, V.; Deuschel-Cornioley, C.; Von Zelewsky, A. Advances in 
Photochemistry; Wiley: New York, 1992; Vol. 17, p 1. (b) Lo, K. K. W.; Li, C. K.; Lau, K. W.; Zhu, N. J. Chem. Soc., Dalton Trans. 2003, 24, 4682. (c) Lo, K. K. W.; Hui, W. K.; Chung, C. K.; Tsang, K. H. K.; Lee, T. K. M.; Li, C. K. ; Lauu, J. S. Y.; Ng, D. C. M. Coord. Chem. Rev. 2006, 250, 1724. (d) Tseng, M. C.; Ke, J. L. ; Pai, C. C.; Wang, S. P.; Huang, W. L. Polyhedron 2006, 25, 2160.

19. Venkatachalam, G.; Ramesh, R.; Mobin, S. M. J. Organomet. Chem. 2005, 690, 3937

20. (a) Nonoyama, M. J. Organomet. Chem. 1975, 86, 263. (b)Steel, P. J. J. Organomet. Chem. 1991, 408, 395.

21. Gul, N.; Nelson, J. H. Organometallics 1999, 18, 709.

22. Aalbersberg, W. G. L.; Barkovich, A. J.; Funk, R. L.; Hillard, R. L.; Vollhardt, K. P. C. J. Am. Chem. Soc. 1975, 97, 5600.

23. (a) Hillard, R. L.; Vollhardt, K. P. C. Angew. Chem. Int. Ed. 1975, 14, 712. (b) Hillard, R. L.; Vollhardt, K. P. J. Am. Chem. Soc. 1977, 99, 4058. (c) Vollhardt, K. P. C. Acc. Chem. Res. 1977, 10, 1.

24. Yamamoto, Y.; Hattori, K.; Nishiyama, H. J. Am. Chem. Soc. 2006, 128, 8336.

25. (a) Grigg, R.; Scott, R.; Stevenson, P. Tetrahedron Lett. 1982, 23, 2691. Grigg, R.; Scott, R.; Stevenson, P. J. Chem. Soc., Perkin. Trans. 1 1988, 1357.

26. (a) Saito, S.; Yamamoto, Y.; Chem. Rev. 2000, 100, 2901. (b) Yamamoto, Y. Curr. Org. Chem. 2005, 9, 503 (c) Kotha, S.; Brahmachary, E.; Lahiri, K. Eur. J. Org. Chem. 2005, 4741.

27. Padwa, A.; Nimmesgern, H.; Wong, G. S. K. J. Org. Chem. 1985, 50, 5620.

28. (a) Xue, P.; Sung, H. S. Y.; Williams, I. D.; Jia, G. J. Organomet. Chem. 2006, 691, 1945; (b) Bianchini, C.; Meli, A.; Peruzzini, M.; Vacca, A.; Vizza, F.; Organometallics 1991, 10, 645; (c) Bianchini, C.; Caulton, K. G.; Chardon, C.; Eisenstein, O.; Folting, K.; Johnson, T. J.; Meli, A.; Peruzzini, M.; Rouscher, D. J.; Streib, W. E.; Vizza, F. J. Am. Chem. Soc. 1991, $113,5127$.

29. Nishiyama, H.; Niwa, E.; Inoue, T.; Ishima, Y.; Aoki, K. Organometallics 2002, 21, 2572 and references therein.

30. (a) Paneque, M.; Poveda, M. L.; Rendon, N.; Meriter, K. J. Am. Chem. Soc. 2004, 126, 1610.

(b) Alvarez, E.; Gomez, M.; Paneque, M.; Posadas, C. M.; Poveda, M. L.; Rendon, N.; Santos, L. L.; Rojas-Lima, S.; Salazar, V.; Mereiter, K.; Ruiz, C. J. Am. Chem. Soc. 2003, $125,1478$.

31. Kezuka, S.; Tanaka, S.; Ohe, T.; Nakaya, Y.; Takeuchi, R. J. Org. Chem. 2006, 71, 543.

32. (a) Gao, S.; Zhang, J.; Zhu, Y. F.; Che, C. M. New. J. Chem. 2000, 24, 739. (b) Chen, W.; Zhao, J.; Lee, J. Y.; Liu, Z. Chem. Lett. 2004, 33, 474. (c) Li, H.; Wang, R.; Hong,Q.; Chen, L.; Zhang, Z.; Koltypin, Y.; Calderon-Moreno, J.; Gedanken, A. Langmuir 2004, 20, 8352. (d) Yu, G. Y.; Chen, W. X.; Zheng, Y. F.; Zhao, J.; Li, X.; Xu, Z. D. Materials Lett. 2006, $60,2453$. 